\title{
Euskal Herriko eta Europako kazetari eta prentsa irakurleak lanbidearen geroari begira. Adostasun eta desadostasunen bilduma ${ }^{1}$
}

\section{Periodistas y lectores vascos y europeos contestan sobre el futuro de la profesión. Una colección de acuerdos y desacuerdos}

\section{Basque and European journalists and press readers looking to the future of the profession. A collection of agreements and disagreements}

\author{
Antxoka Agirre ${ }^{2}$ \\ Alazne Aiestaran ${ }^{3}$ \\ Beatriz Zabalondo 4
}

\section{zer}

Vol. 20 - Núm. 39

ISSN: 1137-1102

e-ISSN: $1989-631 \mathrm{X}$

DOI: $10.1387 /$ zer. 15525

pp. 101-125

2015

Recibido el 4 de marzo de 2015, aceptado el 20 de octubre de 2015.

\section{Laburpena}

Lan honek Euskal Herriko eta Europako prentsa irakurleei eta kazetariei eginiko lau inkesta analitikoren emaitzak, eta horien alderaketak, eskaintzen ditu, azpimarra Euskal Herrikoetan jarriz. Euskal Herrian, 200 irakurle galdekatu dira, eta, 500, Europako bost estatu populatuenetan. Itaundutako kazetariak, aldiz, guztiak ere ibilbide garrantzitsua dutenak eta erantzukizun postuetan dabiltzanak, 19 izan dira Euskal Herrian eta 54 Alemanian, Erresuma Batuan, Italian, Frantzian eta Espainian. Kazetaritzaren etorkizunari begira, irakurleen eta kazetarien artean egon daitekeen sintoniari erreparatu nahi izan zaio, batez ere, eta baita

\footnotetext{
UPV/EHUk ofizialki onartutako (GIU 11/04) HGH (Hedabideak, Gizartea eta Hezkuntza) ikerketataldea da lanaren egilea. Txema Ramirez de la Piscina da talde buru eta, beraz, baita lan honen egile ere.

2 Universidad del País Vasco/Euskal Herriko Unibertsitatea, antxoka.agirre@ehu.eus

3 Universidad del País Vasco/Euskal Herriko Unibertsitatea, alazne.aiestaran@ehu.eus

4 Universidad del País Vasco/Euskal Herriko Unibertsitatea, beatriz.zabalondo@ehu.eus
} 
Euskal Herriaren eta Europaren artean egon daitezkeen ezberdintasun eta parekotasun esanguratsuenei ere.

Gako-hitzak: Kazetaritzaren etorkizuna, Internet erabiltzaileak, kazetaritza digitala.

\title{
Resumen
}

El presente trabajo recoge los resultados de cuatro encuestas analíticas realizadas a periodistas y lectores de Europa y Euskal Herria, centrándose en las realizadas en nuestro territorio. En Euskal Herria se han encuestado a 200 lectores, y en Europa a 500, repartidos entre Alemania, Reino Unido, Italia, Francia y España. Los periodistas encuestados han sido 19 en Euskal Herria y 54 en Europa, todos con una importante trayectoria profesional y con cargos de responsabilidad. Se ha querido evaluar la sintonía sobre el futuro de la profesión y recoger las concomitancias y diferencias entre las respuestas europeas y las locales.

Palabras clave: Futuro del periodismo, usuarios de Internet, periodismo digital.

\begin{abstract}
In this article, we are going to present the results of four analytical surveys with questions asked to press readers and journalists from the Basque Country and Europe. The questions were asked to 200 press readers in the Basque Country and 500 readers in the five most populated states in Europe. 19 professionals are from the Basque Country and 54 from Germany, United Kingdom, Italy, France and Spain. Looking to the future of Journalism we focused specially on the concordance among press readers and professionals, and we can find many significant coincidences and differences among the Basque Country and Europe.
\end{abstract}

Keywords: Future of journalism, Internet users, digital journalism. 


\section{Sarrera}

2008tik hedatu den krisiak kalteturikoen zerrenda zabalduz doa egunez egun. Fenomeno horrek eragindako galerak -larriagoak edo arinagoak- herrialde nahiz ekonomiaren alor guztietan nabaritu dira. Berebat, inork aurreikusten asmatu ez duen fenomeno bat izan da, erreferentziazkotzat jotzen ziren hedabideak ere erabat jokoz kanpo harrapatu zituena. J. M. Pérez Tornerok jada 2008 bukaeran zioen bezala, "ziurrenik ez dira medio guztiak izan, eta ez dira eurak izan errudun bakarrak ere, baina egindako hutsari erantzuten hasi beharra dago, instituzio publiko eta finantzarioekiko mesfidantza, zenbaitetan izu bilakatzeraino, erabatekoa bada, medioen sinesgarritasuna ere ez baita askoz egoera hobean gelditu" (Pérez Tornero, 2008).

Mesfidantza hori ez da modu berean antzematen alde guztietan. Herrialdearen, aldiaren eta medio motaren arabera alda daiteke. Adibide paradoxiko bat jartzearren: medio estatubatuarrekiko mesfidantzak 2012an mende honetako punturik altuena hartu bazuen, \% 60 Gallup txostenaren arabera (Morales, 2013), Puerto Ricon medioak instituzio prestigiotsuenen artean daude (Rodríguez Coto, 2012).

2011 ko Eurobarometroaren datuen arabera (Standard eurobarometer 76, 2012: 13-21), 27en Europar Batasunean irratia da herritarren artean konfiantza gehien sortzen duen medioa (\% 57 mesfidati agertzen den \% 35aren aurrean). Telebista dator jarraian (\% 53aren konfiantza eta \% 42aren mesfidantza). Eta prentsak eta Internetek testa ez dute gainditzen. Lehenaren kasuan mesfidantza \% 51koa da konfiantza agertu duen \% 43aren aurrean. Interneti dagokionez, \% 39 agertzen da mesfidati eta $\% 37$ fidakor (kasu horretan esanguratsua da, herritarren \% 24 dela, iritzi jakin bat agertzen ez dutenen kopurua).

Txanponaren alde bat konfiantza galera bada, bestea salmenten galera eta horren ondorioak izango lirateke. Mendebaldeko herrialde garatuetan erreferentziazko medio guztiak larri dabiltza: AEBetan 120 egunkari desagertu dira oso tarte laburrean (Ramonet, 2011: 28) eta Europan ere bide beretik doaz gauzak: Le Monde, Financial Times, The Independent, The Guardian, Corriere della Sera edo El País bezalako egunkari handietan kaleratzeak eguneroko kontu bihurtu dira.

Gaur herritarrek uko egiten diete atxikimendu betierekoei, batez ere medio handiei dagokienean. Ignacio Ramonetek (2011) 'kazetaritzaren eztanda' deritzona ari gara bizitzen: herrialde garatuetan iritzi lider eztabaidaezin gisa funtzionatzen zuten 'eguzkimedioak' desagertzen edo goitik behera birmoldatzen ari dira, eta ehunka, milaka hedabide txiki-ertain ari dira loratzen, sortzen eta birsortzen, teknologia berrien eta sare sozialen babesean. Aipatu bezala, ordea, medio berri horiek ere ez dute herritarren konfiantza lortzen, ez dute handiek lehen betetzen zuten lekua hartzea lortzen.

Espainian, esaterako, Prisa taldearen zorra 5.000 milioi eurotakoa da, eta $2011 \mathrm{ko}$ urtarrilaren 25ean talde honek 2.500 lanposturen suntsiketa iragarri zuen, alegia bere pertsonalaren \% 18a. 2008tik 2012ra bitartean 6.300 kazetarik galdu zuten euren lanpostua (Ballesteros, 2012: 11), eta FAPEren (Federación de Asociaciones de la Prensa de España) arabera, egun kazetaritzan lizentziaturiko 65.000 lagunetatik 30.000 bakarrik ari dira kazetari gisa lanean. Gainerakoak langabezian edo beste lanbideren batean leudeke (APM, 2013).

Mendebaldeko herrialde garatuetan, batzuen konfiantza faltak eta besteen salmenten jaitsierak erakusten dutenez, bistakoa da nolabaiteko sintonia galera bat ari 
dela gauzatzen medioen erabiltzaileen eta berauetako profesionalen artean. Batetik bestera eragin ezberdinak izan dituen fenomeno batez ariko ginateke, hainbat faktoreren eraginez gertatu dena eta, ondorioz, irtenbide eredu anitzak eskatzen dituena. Euskal Herrian eta Europan, jazotzen denaren diagnostiko bat egiteko saiakera bat da datozen orrialdeetan garaturiko lana. Erabiltzaileen eta medioen arteko sintonia falta izan daitekeelako arazoaren oinarrietariko bat, elkar ulertzea hobetzen laguntzeko asmoz, batzuei eta besteei euren iritzia eskatu zaie eta jasotako datuak alderatu dira.

\section{Marko teorikoa}

London School of Economics-eko Anthony Smith irakasleak (2010: 7) 1960tik 2005era zedarritzen du kazetaritzaren urrezko aroa. Bere hitzetan, aro horri hasiera eman ziotenak TomWolferen Kazetaritza Berriarena bezalako praktikak izan ziren: erreportaje sakonek eta analisiari eta testuinguruari emaniko garrantziak inguratzen gaituen errealitatea hobeto ulertzeko bitarteko bihurtu zuten kazetaritza. Amaiera data, aldiz, eztanda digitalarekin dator bat. Interneterako jauziakhainbat galera ekarri omen ditu.

WAN-IFRA (World Association of Newspapers and News Publishers) elkartearen World Press Trends ${ }^{5}$-aren arabera, 2012an biztanleria helduaren erdiak baino gehiagok kontsumitzen zuen prentsa munduan. 2.500 milioi pertsonek paperean egiten zuten, eta 600 milioik, formatu digitalean. Azken horien artean 500 milioik bertsio digitalaz gain paperekoa ere irakurtzen zuen. Digitalen irakurleriak \% 6ko hazkundea izan zuen $2011 \mathrm{n}$, eta tableten erabiltzaileen artean 10etik 6k adierazi zuen nahiago zuela bertsio digitala paperekoa baino. 2010eko urrian Hanburgon egin zen Editoreen Munduko Biltzarrak iragarri zuen hurrengo bost urteetan paperekoaren salmentak erdira jaitsiko zirela eta irakurleen \% 55ek egunkariak Internet bidez kontsumituko zituztela. Badirudi iragarpena ez dela bere horretan bete, baina erabiltzaileen paperetik sarera lekualdatzeko joera ukaezina dela.

Zabalkundea gorabehera, erabiltzaileen engaiamenduak, frekuentziak (zenbatetan konektatzen diren) eta intentsitateak (konektatzen direnean zenbat egoten diren) arazoak ekarri dizkio, ordea, prentsa digitalari ere. Honela, berriro ere WANIFRAren arabera, Interneten kontsumo osoaren barnean egunkarienak pisu gutxiko datuak dira: bisiten $\%$, online denboraren $\%$ 1,3 eta bisitaturiko orrialdeen $\% 0,9$. Edo AEBetan Interneteko erabiltzaileen 10etik 7k egunkarien webguneak bisitatzen baditu ere, \% 17k bakarrik egiten du egunero. Gehienean webgune horiek doako zerbitzu gisa funtzionatzen dute gainera. Horren harira, Pérez Latre eta SánchezTabernero (2012: 17-18) irakasleek garbi uzten dute doakotasunak eta Interneten garapenak "edukien balioaren gainbehera dramatikoa" ekarri dutela; izan ere, "kontsumitzaileek informazioa eta entretenimendua edonon topa ditzakete, kosturik gabe. Horregatik, hedabide tradizionaletatik aldentzen hasi ziren, gaiak antzekoegiak eta tratatzeko moduak ere iragarriegiak zirelako". Horrek guztiak, jakina, markaren beraren gainbehera ekarri du.

Beraz, paperekotik finantzatzen dira, paperekotik jaten dute, baina, aldi berean, paperekoari bezeroak kentzen dizkiote. Hortaz, 2008an hasi zen krisi ekonomiko orokorrak areagotuta, sektorearen finantzaketa eredua bera jarri da kolokan eztanda digitalarekin.

\footnotetext{
${ }_{5}$ Elkarteak urtero argitaratzen duen txostena. 150 estatutako datuak, sektorearen $\%$ 90, jasotzen dira bertan.
} 
Ezinbestekoa dirudi finantzaketa bide berriak topatzeak. AEBetan azken aldian gehien zabaldu den formula freemium-arena da (Leiva eta Vara, 2010: 338-350). Horren arabera, eduki digital gehienak doan eskainiko dira, baina eduki berezituenak mikro-ordainketen trukean jarri dira eskuragarri. Eta medio txikiagoak martxan jartzeko mezenasgoa edo crowdfundig-a bezalako formulak erabili dira, irakurleen borondatezko ekarpenekin osatuz medioaren finantzaketa. Edozein kasutan, geroz eta nabariagoa da erabiltzaileen artean informazioa sortzeak dakarren kostuaren inguruan pedagogia egin beharra (Nobre, 2010: 103; De Pablos eta Mateos, 2004: 360).

Hala ere, Internet, edo bere finantzaketa arazoak, al dira paperaren gainbeheraren eragile bakarrak? Horretaz gain, eztanda digitalak ekarri duena ez da aurretik ere mendebaldeko kazetaritzaren osasuna erasaten zuten hainbat praktikaren jarraipena baizik: ikerketa kazetaritza kasik desagerraraztea, nazioarteko saila geroz eta gehiago ahultzea, erreportaje sakonen eskasia, analisia low cost informazioarekin ordezkatzea, edukien arinkeria eta azalkeria, infotainmentaren nonahikotasuna, kazetari gazte, otzan eta eskarmenturik gabeak lehenestea beteranoen kaltetan, ofizioaren lan baldintzen degradazioa... Asko dira kalitate eta sinesgarritasun galeraren jatorrian dauden faktoreak, gero sare sozialak informatzaile profesionalen ordezko bihurtu nahi izanak anabasa horren guztiaren areagotzea ekarri badu ere.

Paul Starr (2010: 69) AEBetako Princeton University-ko Woodrow Wilson Eskolako irakasleak esaldi bakar batean laburbildu du hori guztia: "Prentsa gutxiago ustelkeria gehiago" artikuluan: Teknologia berriek ez dituzte ordezkatzen betiko erantzukizunak.

Berehalakotasunarekiko lilurak saturazioa eragiten du eta ezagutza kolapsatzen. Ryszard Kapuscinski-k honela esaten zion bera baino gazteagoa zen kazetari bati (Requena, 2012: 54): "Ez dizuet inbidiarik, berehalakotasuna beldurgarria da, ofizio zahar honen muinean dagoena galtzera zaramatza, informazioaren inguruan gogoeta egin eta 'bestea' ezagutzeko aukera galtzera”. Eta Albert Camusek ere, jada 1944an, oso argi adierazi zuen (Ramonet, 2011: 19): "Azkar informatu nahi da ongi informatu beharrean eta hor egia ez da irabazten ateratzen”. Bere ustez, argitasuna, desobedientzia, ironia eta burugogorkeria dira kazetari on ororen lau mandamenduak (Ballesteros, 2012: 14). Berehalakotasuna edo ikuskizuna, gaur hainbat medioren jardueran ezinbestekoak biak, ez ditu inondik inora aipatzen.

Salaverriak (2012: 12) dioen bezala, "kazetaritzak ez du inoiz dagokion funtzio soziala betetzeko egun dituen bezain beste bitarteko izan". Badirudi, ordea, funtzio sozial hori betetzen ez duela behar den bezala asmatu azken aldian, balio sozial hori agerikoa balitz ordaintzeko prestutasun gehiago agertuko bailuke erabiltzaileak.

Hala, paperekoaren desagertze data iragartzera ere iritsi izan dira zenbait aditu. Martinez Albertos irakasleak 1998an esan zuen 2020an gertatuko zela. Eta Jeff Jarvis Interneteko aditua bat dator data horrekin, bere iragarpena askoz ere beranduago burutu bazuen ere, 2007an. Philiph Meyer (2004) kazetari eta Ipar Karolinako Unibertsitateko irakasleak, aldiz, 2043an jarri zuen mugarria. Data eta apustuak gorabehera, inork ez du zalantzan jartzen gaixoaren larritasuna.

Azkenik, aipatu behar da euskarazko kazetaritzari buruzko ikerketan hainbat lan aurki daitezkeela, esaterako, Camacho (2002), Arana et al. (2000), Zuberogoitia (2003), Aiestaran (2007 eta 2011), Zabaleta et al. (2010), Zabalondo (2011), Díaz Noci (2012), Bidegain (2013), baina inork ez duela espresuki jorratu sektorearen krisiaren gaia. HGH taldeak berriki landu eta argitaratu dituen hainbat lan -Aiestaran et 
al. (2014) eta Ramirez de la Piscina et al. (2014a, 2014b, 2015a eta 2015b)- hutsune hori betetzen hastera letozke. Tartean, lan hau, erabiltzaileen eta profesionalen arteko sintonian azpimarra jartzen duena.

\section{Helburuak, hipotesiak eta iker-galderak ${ }^{6}$}

Ikerketaren helburu nagusia prentsa irakurleek nahiz profesionalek kazetaritzaren etorkizuna nola planteatzen duten ezagutzea da. Horrez gain, europar kazetarien nahiz irakurleen iritziekin alderatu nahi dira euskara bezalako hizkuntza gutxitu batean diharduten kazetarien eta irakurleen inguruan jasorikoak.

(H1) Egungo prentsaren egoera baloratzerakoan, ikuspegi ezberdinak, eta zenbaitetan baita kontrajarriak ere, izan ditzakete profesionalek eta erabiltzaileek, albistearen ekoizpenaz duten ezagutza eta aztergai dugun alorrera gerturatzeko izan dezaketen motibazioa ezberdinak baitira.

Hipotesi horri lotuta honako iker-galderak planteatzen dira:

RQ1- Ba al dago ezberdintasun nabarmenik prentsa digitalaren irakurleek eta kazetariek adierazten dituzten iritzien artean?

RQ2- Asebetetzen al ditu irakurle eta kazetariak egunkari digitalek eskaintzen duten doako informazioak? Eta ordainpekoak? Irakurleak prest al daude kalitatezko edukiengatik ordaintzeko?

RQ3- Zeinek bermatzen du irakurle eta profesionalen arabera gehiago informazio eskubidea eta adierazpen askatasuna: hedabide tradizionalek (prentsa, irratia eta telebista) edo digitalek?

RQ4- Irakurle nahiz profesionalen arabera berehalakotasuna, kalitatea eta sinesgarritasuna bateragarriak al dira kazetaritzaren jardunean?

RQ5- Nola baloratzen dute profesionalek eta irakurleek egungo interaktibotasun maila? Eta etorkizunekoa?

RQ6- Irakurle nahiz profesionalen arabera iraungo al du papereko prentsak 2020an? Euren aburuz nolakoa izango da sareko informazioa?

(H2) Bigarren hipotesi gisa, galdera horien erantzunetan Europan jasotakoen eta Euskal Herrian jasotakoen artean ezberdintasunak aurki daitezkeela planteatzen da. Hain zuzen ere, Euskal Herrikoak hedabide komunitarioak direlako eta bertan dabiltzan profesionalek nahiz medioen irakurleek bestelako sentsibilitate bat dutelako.

RQ7- Ikerketa honetan planteatzen zaizkien kontuen inguruan ba al dago ezberdintasunik Euskal Herrian kazetariengandik nahiz prentsa irakurleengandik jasotako erantzunak Europako hizkuntza handietako kazetariengandik nahiz irakurleengandik jasotakoekin alderatzen baditugu?

\footnotetext{
${ }^{6}$ Espainiako Zientzia eta Berrikuntza Ministerioak diruz lagundutako Evolution of the assessed News Quality in European reference media (2000-2014) ikerketa-proiektuaren (CSO 2011-23237) emaitzen zati bat da lan hau. UPV/EHUk ere diruz lagundu du. Bestalde ikerketa proiektuaren beste emaitza batzuk Journalism, Revista Latina de Comunicación Social, Uztaro eta Journalism, Theory, Practice and Criticism aldizkarietan argitaratu dira.
} 


\section{Metodologia}

Iker-galderak erantzuten saiatzeko erabilitako baliabide nagusia inkestak izan dira. Lau inkesta burutu dira guztira: euskal prentsaren irakurleei zuzendurikoa, euskal prentsako profesionalei zuzendurikoa, europar prentsaren irakurleei bideratu zitzaiena eta profesionalei eginikoa.

Inkestak egoera batzuk zergatik ematen diren deskribatu eta azaltzeko xedea duen inkesta analitiko klasikoaren gida-lerroak jarraituz diseinatu ziren. Modalitate horretan bi aldagai edo gehiagoren hautaketarekin kontrastatu ohi da ikerketaren hipotesia, elkarren artean egon daitezkeen harremanak eta balizko inferentzia azaltzaileak sortuz (Wimmer eta Dominick, 1996: 113-115).

Inkesten diseinua HGH ikerketa taldeak burutu zuen 2013ko iraila eta urria bitartean. Aipaturiko iker-galderak hartu ziren oinarritzat eta honako alorrak jorratu nahi izan ziren besteak beste: edizio digitalen kalitatea, informazio eta adierazpen askatasunak, doako eta ordainpeko informazioaren ahulgune eta indarguneak, eskaintzen den informazioaren asegarritasuna eta prentsa irakurleen ordaintzeko prestasuna, etorkizunera begira hobetu beharrekoak eta 2020ko egoeraren aurreikuspena.

Irakurleei zuzenduriko inkestak 2013ko abenduan burutu ziren, gauzatze lanak $\mathrm{CIES}^{7}$ enpresari esleitu ondoren. 31 galdera zituen inkestak. Euskal Herrikoa 200 laguni helarazi zitzaion ${ }^{8}$. Europako inkesta egiteko, kontinentearen mendebaldeko bost herrialde populatuenak aukeratu ziren: Alemania, Erresuma Batua, Frantzia, Italia eta Espainia, eta bakoitzean 100 laguni bideratu zitzaion galdetegia ${ }^{9}$.

Profesionalei zuzenduriko inkestak 2013ko abendua eta $2014 \mathrm{ko}$ martxoa bitartean burutu ziren. Kasu horretan, 29 galdera egin zitzaizkien, horietatik 19 galdera irakurleei eginiko berak ziren eta beste hamar profesioaren ingurukoak. Azken horietatik bost kode irekikoak ziren, alegia, egituratu gabeko erantzunak onartzen zituzten.

Elkarrizketatuaren profila berdina izan zen Euskal Herrian eta Europan: kazetari esperientziadunak eta, aldi berean, kasu gehienetan, hedabideetan edizio-ardurak zituztenak. Euskal Herrian, ikertaldea 30 profesionalekin jarri zen kontaktuan. Horietatik $19 \mathrm{k}$ bete zuten inkesta ${ }^{10}$. Elkarrizketatuei aukeran eman zitzaien euren iritziak

7 Enpresa horrek esperientzia handia du audientzien neurketan eta irabazle suertatu zen UPV/EHUk horretarako antolaturiko lehiaketan.

8 Online nahiz telefono elkarrizketa teknika erabili zen sexuaren (107 gizonezko eta 93 emakumezko) adinaren (62, 18-34 urtekoen artean, 80, 35-49 urtekoen artean eta 58, 50-75 urtekoen artean) eta lurraldearen (22 Araban, 46 Bizkaian, 32 Gipuzkoan, 50 Nafarroan eta 50 Iparraldean) araberako estratifikazioarekin. Lanak \% 95eko konfiantza maila eta $\pm \% 2,2 \mathrm{ko}$ gehienezko hutsegite tartea ditu.

9 Fitxa teknikoa: 100 lagun elkarrizketatu ziren herrialde bakoitzeko. Erabilitako teknika online elkarrizketa izan zen sexuaren (266, gizonezko eta 234 emakumezko) eta adinaren (169 18-34 urtekoen artean, 172, 35etik 49 bitartekoen artean eta 159, 50 eta 75 urte bitartekoen artean) araberako estratifikazioarekin. Konfiantza maila $\% 95$ ekoa izan zen, eta gehienezko hutsegite tartea, $\% \pm 4,5$ ekoa.

${ }^{10}$ Ikerketa taldeko kideek burutu zuten inkestatzaile lana. Lehen kontaktua telefonoz eginez eta galdetegiaren joan-etorrikoa posta elektronikoz bideratuz. Profesionalek espektro zabala islatzen zuten bai geografiari eta baita ideologiari zegokionean ere. Denak ziren zuzendari, zuzendariorde, webmaster, erredaktoreburu edo esperientzia handiko berriemaileak. Bina ordezkari zeuden ondorengo hedabideetatik: El Correo, El Diario Vasco, eta Deia. Beste bi ikerkuntzan diharduten profesionalak ziren: bata, Nafarroako Unibertsitatean, eta bestea, Renoko Unibertsitatean. Ordezkari bana zegoen ondorengo komunikabideetatik: Gara, Berria, Argia, Diario de Navarra, El País, EITB, Euskalerria irratia, Euskal irratiak, Baleike aldizkaria eta Tokitan TVtik. Hemeretzigarrena 
eta izenak publiko egin edo ez erabakitzeko. Hamarrek ez zuten erreparorik izan beren izenak argitaratzeko, bostek, identitateaz gain, euren iritzia argitaratzeko baimena eman zuten, eta beste lauk nahiago izan zuten dena gordean mantentzea.

Aldi berean, Europako kazetarien artean ere egin zen inkesta. Kasu horretan, ikertaldeak kanpoko enpresa-talde baten, The Research Alliance (TRA) institutu-sare europarraren, laguntza behar izan zuen ${ }^{11}$. Europako bost estatu populatuenetako 250 kazetariren zerrenda batetik 54k onartu zuten ikertaldearen proposamena. Oraingoan ere denak ziren eskarmentu handikoak eta formatu ezberdinetan egiten zen lanaren adierazgarri izan zitezkeenak ${ }^{12}$. Inkestari erantzundako gehienek -38- nahiago izan zuten iritzirik eta identitaterik ez argitaratzea. Gainerako 16 profesionalek ez zuten arazorik izan izenak eta iritziak argitara emateko.

\section{Emaitza orokorrak}

Iker-galderen arabera zazpi bloketan banatu da emaitzen analisia:

- Euskal eta europar prentsa irakurleen kontsumo ohiturak.

- Doakoaren eta ordainpekoaren asebetetze eta ahulguneak.

- Ordaintzeko prestasuna.

- Azkartasunaren eta sakontasunaren arteko bateragarritasunak.

- Adierazpen askatasunari buruzkoak.

- Etorkizunean hobetu beharrekoak.

- 2020: Etorkizuneko kazetaritzaren ezaugarriak.

komunikazio aholkulari ezaguna zen. Horretarako baimena emandako kazetarien izenak honakoak dira: Juan Carlos Martinez eta Cesar Coca (El Correoko zuzendari eta zuzendari ondokoa), Bingen Zupiria eta Jose Antonio Rodríguez (Deiako zuzendari eta webmaster-a), Iñaki Soto, Garako zuzendaria, Juan Mari Gastaca ElPais-Pais Vasco kazetako zuzendaria, Haritz Rodriguez Tokitan TVko zuzendaria, Nerea Azurmendi DiarioVascoko erredaktore esperientzia handikoa, Juan Kruz Lakasta Euskalerria irratiko erredaktore historikoa , Iban Arregi Berriako kontseilari ordezkaria, Gorka Zabaleta Baleike aldizkariko zuzendaria, Jose Luis Aizpurua Euskal Irratiak kateko erredaktore burua, Alfonso Sanchez-Tabernero Nafarroako Unibertsitateko errektorea eta komunikazioan aditua, Imanol Murua Renoko Unibertsitateko Center of Basque Studies-eko ikerlaria eta Berriako kazetaria eta Pilar Kaltzada komunikazio aholkularia.

${ }^{11}$ Europako inkestak TRA institutu soziologikoen sareak egin zituen. Landa-lana honako enpresa hauen ardura izan zen: CIES S.L. Espainian, Cohesium Frantzian, MarketingSciences Erresuma Batuan, Opinión Alemanian eta Art Italian. Europako profesionalei telefono bidez egin zitzaien inkesta. Zenbait kasutan nahiago izan zuten e-postaz erantzun. 54 profesionaletatik, 12 Frantziakoak ziren; 11na Espainia eta Italiakoak, eta 10na Alemania eta Erresuma Batukoak.

${ }^{12}$ Inkesta erantzun zuten Erresuma Batuko kazetariak honako hedabideetan ari ziren lanean: The Independent, Sunday Mirror, The Guardian, The Daily Telegraph, Daily Express Online, Sky Sport News, The Times eta The Mirror-en. Frantziarrak honakoetan: TF1 eta TF1-LCI, TV Grandes Chaines telebista kateak eta Sud-Ouest, Le Point eta Le Figaro. Alemaniako medioen zerrenda hau izan zen: BR-TV, NDR-TV, Radio Bielefeld, Radio Teddy Tageszeitung TAZ, SpiegelOnline eta Möller NeueMedien Verlags $\mathrm{GmbH}$. Italiako kazetariak honako medioetatik erantzun zituzten galderak: $\mathrm{Co}$ rriere della Sera, La República, Grupo Mondadori, Il Fatto Quotidiano, Il Matino eta Il Messaggero. Azkenik, Espainian inkestaturikoak medio hauek zituzten lantoki: El País, Abc, Periódico de Catalu$\tilde{n}$ a, Eldiario.es, Faro de Vigo, Infolibre, As, El Mundo deportivo eta Vilaweb. 


\subsection{Euskal Herriko eta Europako prentsaren irakurleen kontsumo ohiturak}

Euskal erabiltzaileen kasuan, hizkuntza hautuarekiko galdera batzuk ere planteatu ziren. Honela, aipa daiteke galdekaturikoen \% 72aren ama hizkuntza gaztelera, \% 14arena frantsesa, eta \% 11rena euskara izanik, medio digitaletan nabigatzeko erabiltzen duten lehen hizkuntza gaztelera dela galdekaturikoen \% 77arentzat, frantsesa $\% 17$ arentzat eta euskara \% 6arentzat. Bigarren hizkuntza bezala ingelesa erabiltzen dute (\% 44), euskara (\% 42), gaztelera (\% 28) eta frantsesaren (\% 20) aurretik. Euskararen diglosia eta ingelesa gutxika gure gizartean hartzen ari den indarra ilustratzen duten datuak.

Galdekatu diren erabiltzaile guztiek azken astean Interneten sartu-irtenen bat eginikoak behar zuten ${ }^{13}$. Astean medio digital batera zenbatero konektatzen diren galdetu zaie eta egunean zenbat denbora ematen duten horretan. Euskal eta europar ${ }^{14}$ prentsa irakurleen artean ez da ezberdintasun esanguratsurik ikusten, ez bada euskal irakurleek maiztasun handiagoz eta denbora gehiagoz kontsumitzen dutela. 1. eta 2. grafikoetan ikus daitekeenez, balio handienetako ardatzetan (Egunean bi aldiz edo gehiago, Egunean ordubete inguru...) balio handiagoak dituzte.

1. grafikoa. Medio digitalen irakurketa astean.

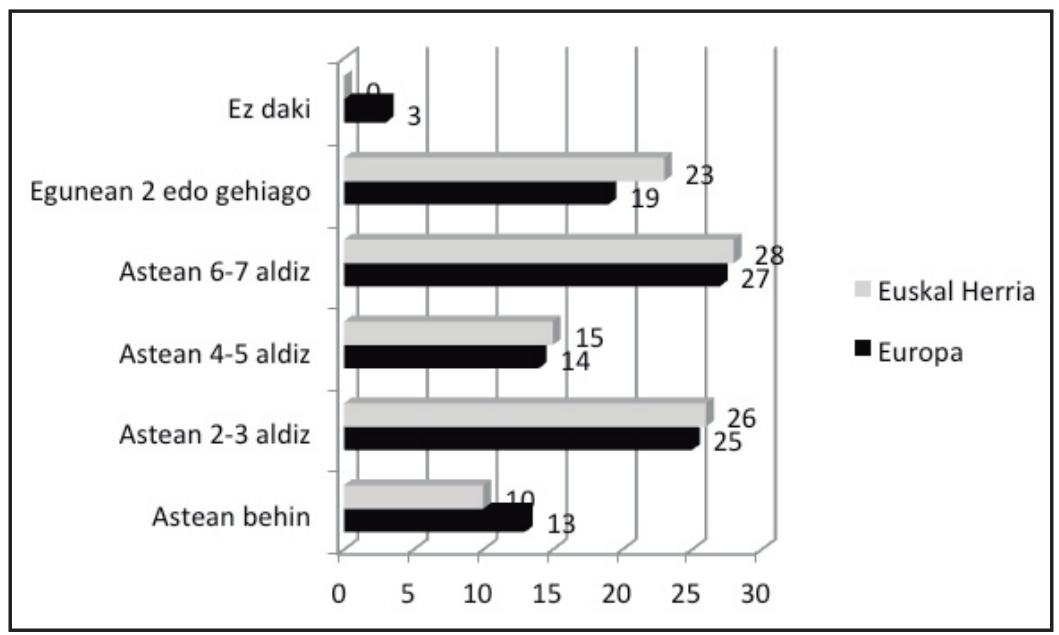

Iturria: UPV/EHUko HGH Ikerketa Taldeak diseinaturiko inkestetan oinarriturik CIESek buruturiko galdeketak.

Bestelako erantzun batzuetan nabarmenagoak dira aldeak. Esaterako, medio digitalak irakurtzeko erabiltzen diren gailuei dagokienean euskal internauta gailu tra-

\footnotetext{
${ }^{13}$ CIESen ikerketen arabera, EAEren kasuan, biztanleriaren $\% 72 \mathrm{k}$ egin du sartu-irtenen bat Interneten eta $\%$ 86k irakurri du komunikabideren bat. Nafarroaren kasuan $\% 75$ eta $\% 81$ dira portzentaje hauek hurrenez hurren, eta Europaren kasuan batez beste $\% 73$ eta $\% 80$.

${ }^{14}$ Batez bestekoak erabiltzen dira grafikoetan, alegia EAE, Nafarroa eta Iparraldeko emaitzen bataz bestekoa batetik eta Alemania, Erresuma Batua, Italia, Espainia eta Frantziako emaitzen bataz bestekoa bestetik.
} 
dizionalagoekin aritzen dela ikus daiteke: euskal herritarren kasuan \% 61 mahai gaineko ordenagailutik, \% 53 ordenagailu mugikorretik, \% 31 smartphonetik eta $\% 16$ tablet-etik; europarren kasuan \% 57ordenagailu mugikorretik, \% 54 mahai gaineko ordenagailutik, \% 35 smartphonetik eta $\% 22$ tabletetik ${ }^{15}$. Edo zein medio mota kontsumitzen duen galdetzerakoan, euskal irakurleen artean prentsa digitalaren nagusitasuna nabarmena da: prentsa digitala $\%$ 98, Irrati edo Tb-en webguneak \% 23 , YouTube $\%$ 27, online bakarrik argitaratzen diren medioak \% 19. Europarren kasuan datuak orekatuagoak dira: prentsa \% 77, Irrati edo Tb-en webguneak \% 41, YouTube \% 35 online bakarrik argitaratzen diren medioak \% 35 .

2. grafikoa. Medio digitalen kontsumoa egunean.

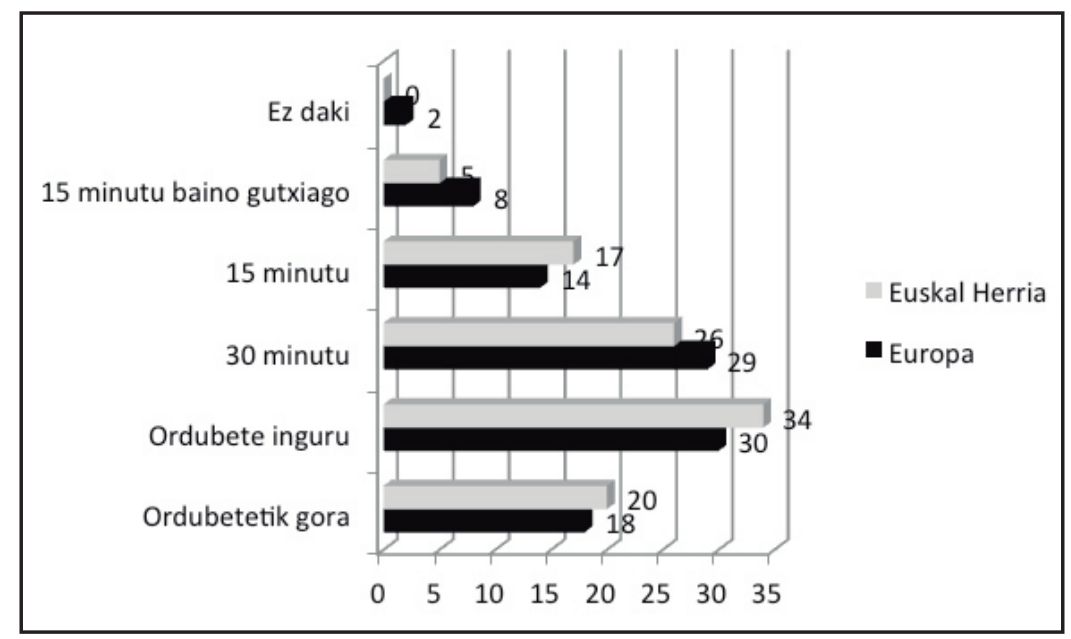

Iturria: UPV/EHUko HGH Ikerketa Taldeak diseinaturiko inkestetan oinarriturik CIESek buruturiko galdeketak.

Deigarria suertatzen den beste datu multzo bat medioekiko fideltasunaren ingurukoa da. Euskal erabiltzaileak, 3. grafikoan ikus daitekeen bezala, dezente fidelagoak dira medio jakin bati. Europarrak gehiago dira lehen klikean pluraltasuna bilatzen dutenak edo irizpide jakinik gabe konektatzen direnak.

Azkenik, kontsumoari dagokionez, irakurleenak eta kazetarienak alderatu nahi izan dira. Horrela, 4. eta 5. grafikoetan ikus daiteke, irakurleen artean doako medioen kontsumoa erabat nagusitzen dela (\% 89 Euskal Herrian eta \% 88 Europan), eta kazetarien artean, ordea, doakoa eta ordainpekoa konbinatzen dituen kontsumoak ere baduela bere garrantzia (\% 42 Euskal Herrian eta \% 61 Europan). Deigarria da alor horretan bateko eta besteko irakurleen artean oso portzentaje altuak ikusten direla, eta kazetarien artean, ordea, askoz ere ezberdintasun nabarmenagoak topatzea (adibidez, doakoa bakarrik kontsumitzen duten kazetariak \% 58 dira Euskal Herrian eta \% 35 Europan).

\footnotetext{
${ }^{15}$ Baturak 100 baino gehiago ematen duenean erabiltzaileari erantzun posible bat baino gehiago hautatzeko aukera eman izan zaiolako da.
} 
3. grafikoa. Medioekiko fideltasuna.

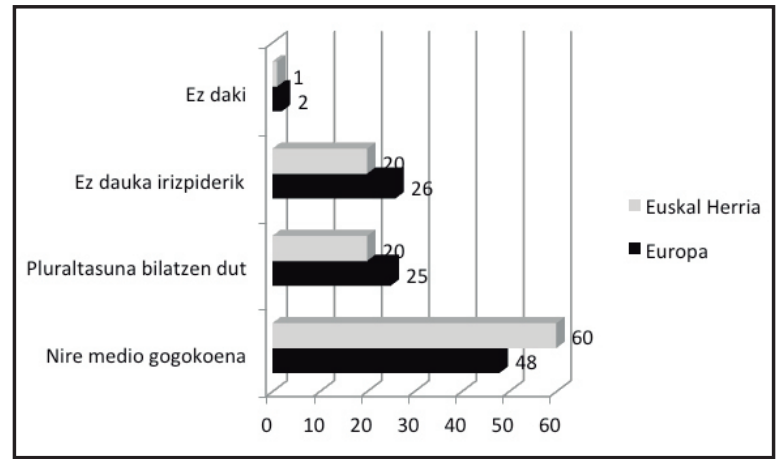

Iturria: UPV/EHUko HGH Ikerketa Taldeak diseinaturiko inkestetan oinarriturik CIESek buruturiko galdeketak.

4. grafikoa. Irakurleen ordainpeko eta doako kontsumoak.

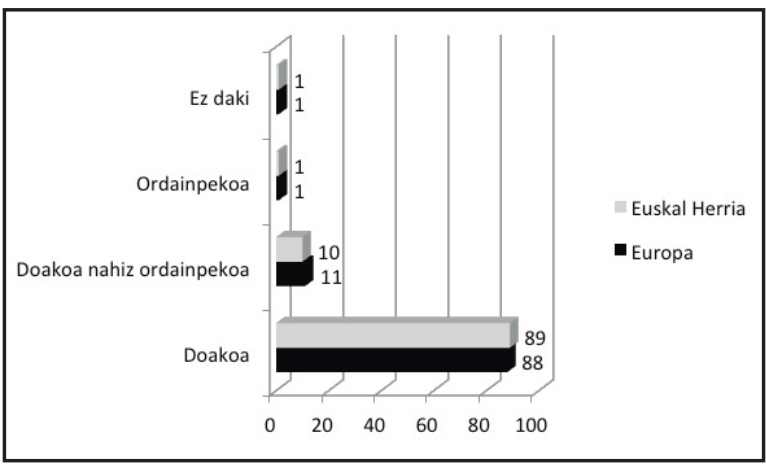

Iturria: UPVIEHUko HGH Ikerketa Taldeak diseinaturiko inkestetan oinarriturik CIESek buruturiko galdeketak.

\section{5. grafikoa. Kazetarien doako eta ordainpeko kontsumoak.}

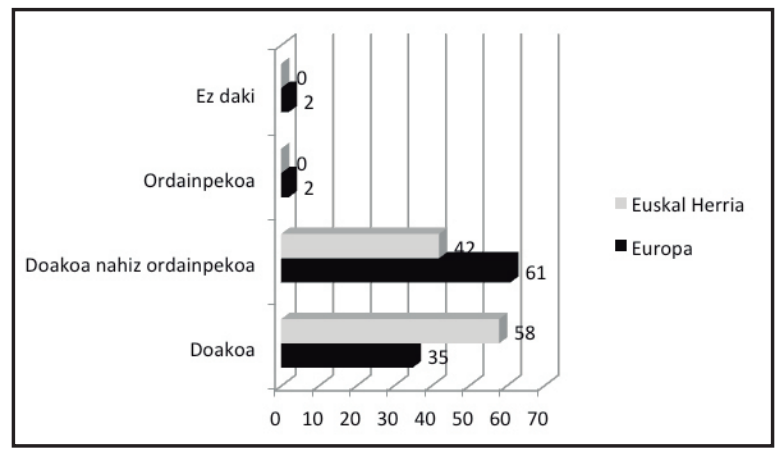

Iturria: UPV/EHUko HGH Ikerketa Taldeak diseinaturiko inkestetan oinarriturik HGH taldea berak eta TRA (TheResearchAlliance) institutu sareak buruturiko galdeketak. 


\subsection{Doako prentsaren nahiz ordainpekoaren asebetetze mailak eta ahulguneak}

Euskal Herrian eginiko inkestetan, ordainpeko edukiei dagokionez, prentsa irakurleen portzentaje handienak ez du iritzi garbirik, \% 72k hain zuzen ere; multzo horretan baitaude ez dakitela erantzun dutenak (\% 21) eta ordainpekorik ez dutela inoiz kontsumitzen erantzun dutenak ere (\% 51). Kazetarien kasuan, portzentaje hori askoz baxuagoa da: \% 26. Kontsumo altuagoaren adierazgarri.

Hortik aurrera, ondoriozta daiteke bai ordainpeko bai doako edukiei dagokionez, kazetariak kritikoago agertzen direla irakurleak baino.

Hortaz, ordainpekoak kontsumitzen dituzten kazetarien artean gehiago dira batzuetan asebetetzen dituela erantzuten dutenak (\% 48) baiezkoa erantzuten dutenak (\% 21) baino, eta irakurleen kasuan parez pare daude bi balio horiek. Edo doakoak asebetetzen dituen irakurleen ehunekoa $\% 77$ da, eta profesionalena \% 42. 6. eta 7.grafikoetan daude irudikatuta Euskal Herriko aipatutako datu guztiak.

6. grafikoa. Doako edukien asebetetze maila.

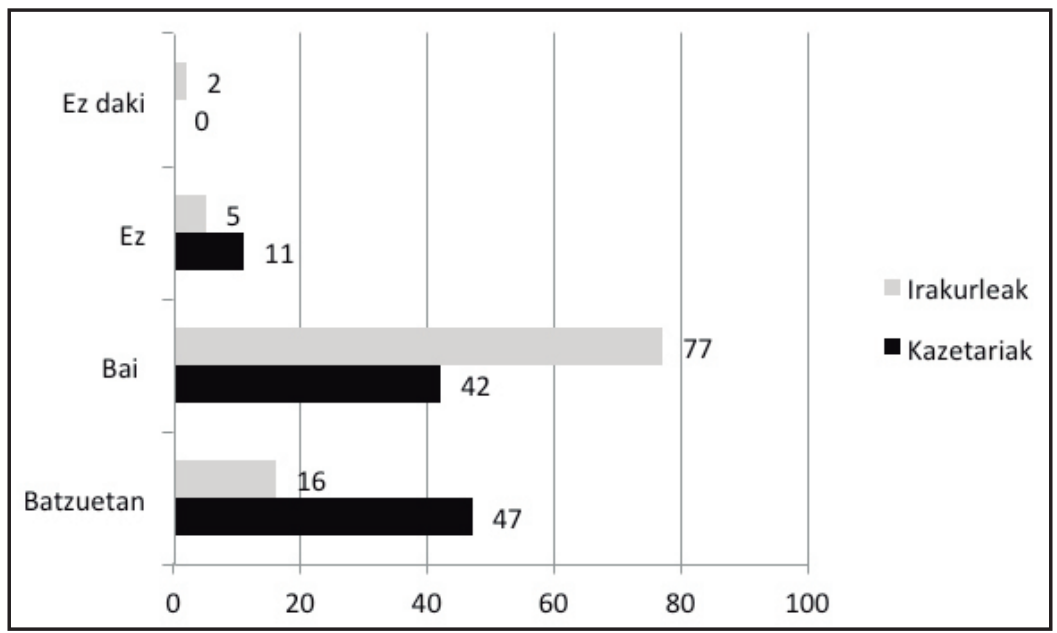

Iturria: UPV/EHUko HGH Ikerketa Taldeak diseinaturiko inkestetan oinarriturik taldeak berak eta CIESek buruturiko galdeketa.

Europan ere joera berdinak nabarmendu daitezke. Ezberdintasunik handiena ordainpekoen inguruan iritzirik ez dutenen portzentajean legoke ('Ez dakit' aukera markatu dutenak): irakurleen $\% 30$ da eta kazetariena 0.

Era berean doako eta ordainpekoen ahulguneez galdetu zaie bai euskal irakurle eta kazetariei nahiz europarrei. Badaude alde esanguratsuak. Lehenengoa iritzi faltaren inguruan: irakurleen kasuan askoz ere altuagoa da (doakoetan irakurleen \% 24 vs. kazetarien $\% 5$ eta ordainpekoetan $\% 59$ vs. \% 32) kazetarien ezagutza, normala denez, handiagoa denaren seinale. Europan ere antzeko datuak aurki daitezke: doakoetan irakurleen $\% 23$ vs. Kazetarien \% 4, eta,ordainpekoetan, irakurleen \% 42 vs. kazetarien \% 19. 
7. grafikoa. Ordainpeko edukien asebetetze maila.

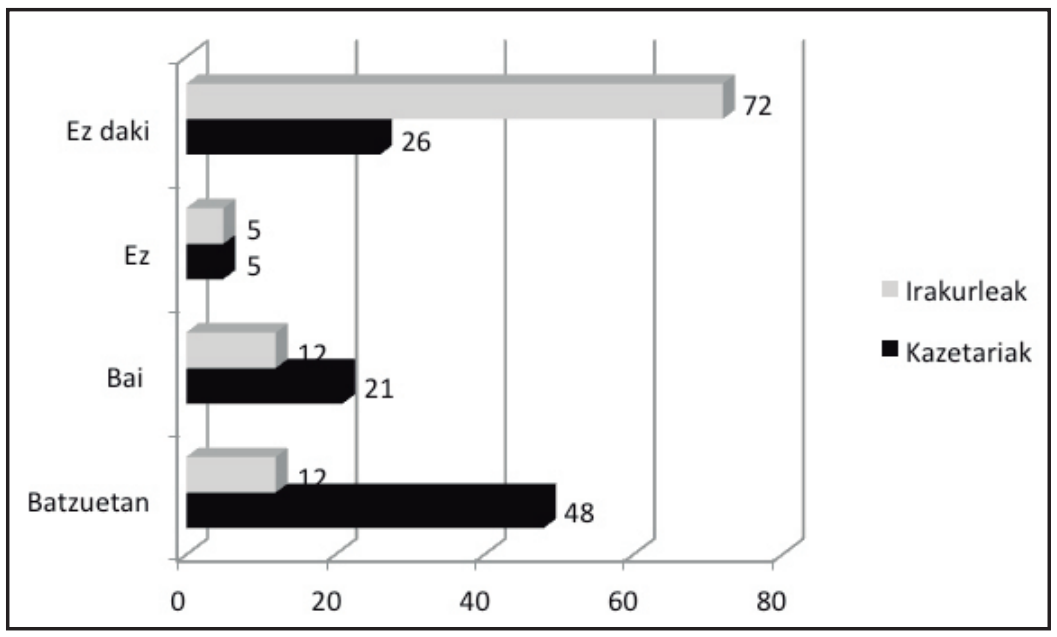

Iturria: UPVIEHUko HGH Ikerketa Taldeak diseinaturiko inkestetan oinarriturik HGH taldea bera eta CIESek buruturiko galdeketak.

Kazetariak askoz ere kritikoago azaltzen dira, berriro ere ezagutza sakonago baten ondorio gisa. Doako prentsarenkasuan, azalkeria da gehien aipatzen den ahulgunea: kazetarien \% 79k eta irakurleen \% 32k. Europan ere hori da gehien aipatzen den ahulgunea, eta antzeko proportzioetan: profesionalak \% 61 eta erabiltzaileak $\% 38$.

8. grafikoa. Doako informazioaren ahulguneak.

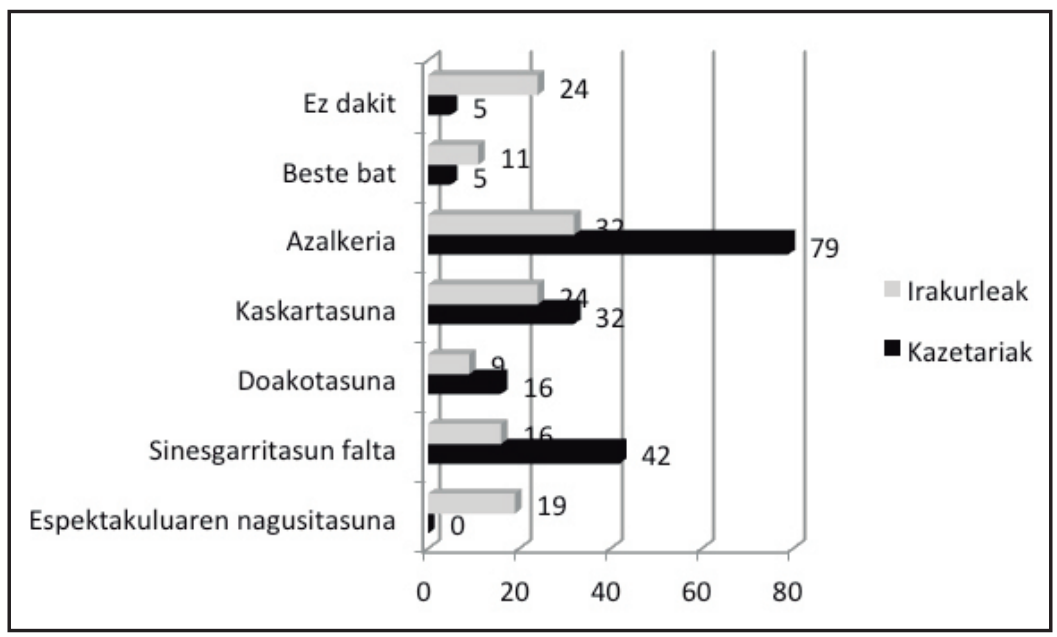

Iturria: UPVIEHUko HGH Ikerketa Taldeak diseinaturiko inkestetan oinarriturik HGH taldea bera eta CIESek buruturiko galdeketak.

Ordainpeko prentsaren kasuan, ikus-entzunezko baliabideen eskasia da kazetariek gehien aipatzen duten ahulgunea (\% 32); irakurleek, aldiz, ordaintzen denarekiko 
eskaintzen den kalitate eskasa da gehien aipatzen dutena (\% 16). Europaren kasuan, zenbaitetan aurki daitezkeen akatsak seinalatzen dituzte kazetariek (\% 26) eta prezioarekiko eskaintzen den kalitate eskasa irakurleek (\% 20).

9. grafikoa. Ordainpeko informazioaren ahulguneak.

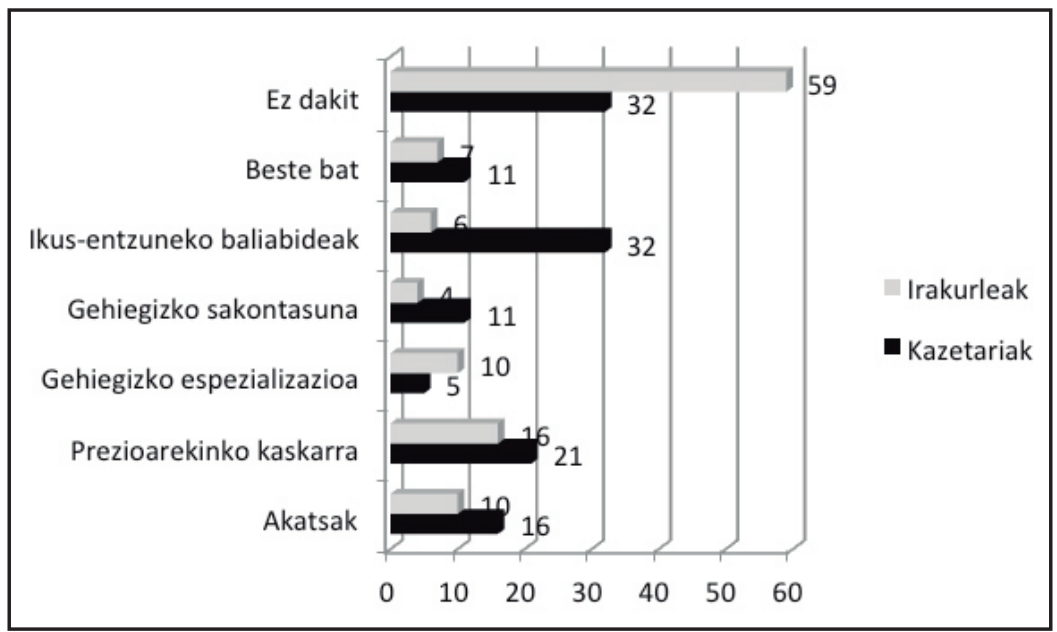

Iturria: UPV/EHUko HGH Ikerketa Taldeak diseinaturiko inkestetan oinarriturik HGH taldea bera eta CIESek buruturiko galdeketak.

Ahulguneez ez ezik, indarguneez ere galdetu zaie batzuei eta besteei batean eta bestean. Euskal Herriko inkesten kasuan, doakoaren indargune nagusiak azkartasuna eta doakotasuna dira erabiltzaile nahiz kazetarientzat, Europakoetan bezala. Ordainpekoetan sinesgarritasuna eta interaktibotasuna aipatzen dituzte euskal irakurleek eta Europako irakurle nahiz kazetariek. Euskal kazetariek, sinesgarritasuna eta sakontasuna.

\subsection{Ordaintzeko prestasunari buruzko iritziak}

Krisiaren sorburuen artean sareko informazioaren doakotasuna seinalatzen du galdekaturiko kazetarien herenak. Eta pixkanaka, sarreran adierazi den bezala, irtenbide gisa hasiak dira editoreak sareko edukiengatik ordainketa geroz eta modu zabalagoan eskatzen. Puntu honetan, ordea, badirudi kazetari eta irakurleak ez datozela bat. Epe motzean, irakurleak sareko edukiengatik ordaintzeko prest egongo liratekeen galdetuta, kazetariek uste dute baietz (\% 16) edo salneurriaren arabera baietz (\% 42). Irakurleei galdetuta \% 7ra eta \% 29ra jaisten dira hurrenez hurren kopuru horiek.

Europarekin alderatuz, eta ikusi den bezala, ordaintzeko kultura dezente baxuagoa izan arren, deigarria da kazetariek uste dutenaren eta prentsa kontsumitzaileek diotenaren arteko aldea hain handia ez izatea. Euskal Herriaren kasuan, 10. grafikoan ikus daitekeenez, ordaintzeko prest dauden irakurleen ('Bai' aldagaia) eta profesionalen arabera, prest egon daitezkeen artean 9 puntukoa da diferentzia, Europaren kasuan 11 puntukoa. 'Zenbatekoaren arabera' aldagaiari dagokionez, berriz, 
13 puntukoa da aldea Euskal Herrian, eta Europan 22koa. Euskal Herriko inkestan bestelako medioen irakurle nahiz kazetariak ere sartu dira, baina hedabide komunitarioek duten pisua ikus daiteke sintonia handiago horren atzean.

10. grafikoa. Ordaintzeko prestasuna.

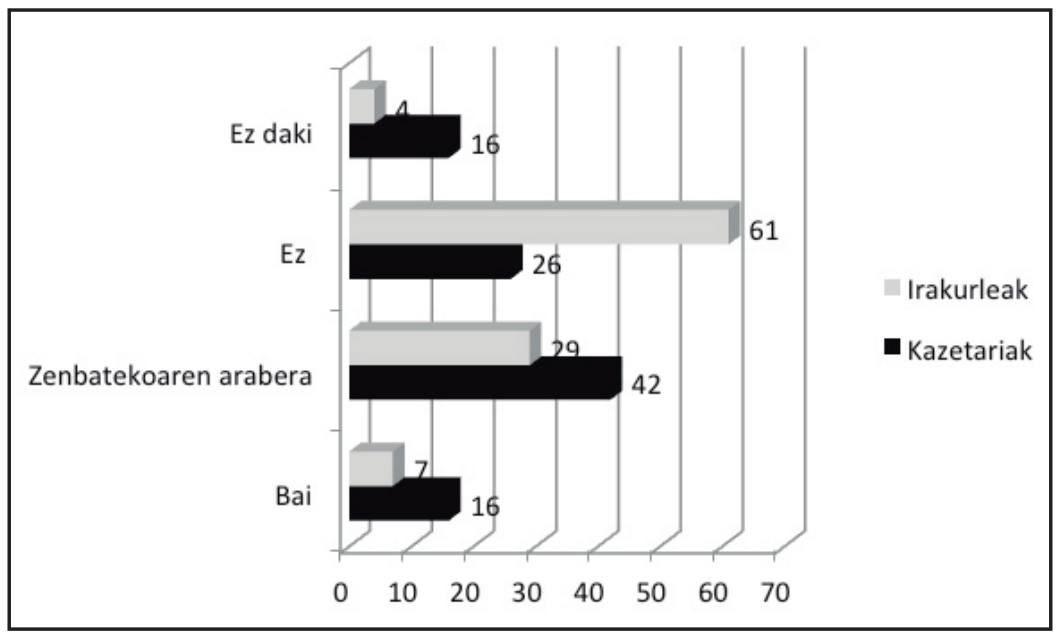

Iturria: UPV/EHUko HGH Ikerketa Taldeak diseinaturiko inkestetan oinarriturik HGH taldea berak eta CIESek buruturiko galdeketak.

Xehetasunetara jaitsiz, euskal inkestan egunkariz egunkari jasotako emaitzei erreparatzen badiegu, ikus daiteke Berriaren edizio digitalaren irakurlearentzat haren kalitatea ona dela portzentaje handienean, $\% 67$. Oso ona dela diotenak \% 11 dira, eskasa dela diotenak \% 12 eta txarra dela diotenak \% 9. Bestalde, Berria eta Gara dira Interneteko edukiak ordaintzeko prest dauden irakurle gehien dituzten bi egunkariak. Ordaintzeko prest daudenei zenbatekoaren arabera ordaintzeko prest daudenak gehituta \% 33ra iristen dira balioak lehenengoaren kasuan eta \% 30ra bigarrengoaren kasuan. Bi horiek dira euskal kioskoetan community mediatzat har daitezkeenak, irakurleak baitira bi kasuetan akziodun nagusi. Eta inkestaren emaitzetan ikus daitekeen gisa, horretako medioen irakurleek bestelako prestasuna dutela euren egunkaria lagundu eta babesteko.

1. Taula. Edizio digitalak.

\begin{tabular}{|l|c|c|c|c|c|c|}
\hline Ordaintzeko prestutasuna & Berria & Correo & $\begin{array}{c}\text { Grupo } \\
\text { Noticias }\end{array}$ & $\begin{array}{c}\text { Diario } \\
\text { Vasco }\end{array}$ & Gara & $\begin{array}{c}\text { Diario } \\
\text { Navarra }\end{array}$ \\
\hline Bai & $\% 12$ & $\% 10$ & $\% 4$ & $\% 9$ & $\% 12$ & $\% 4$ \\
\hline Bai, zenbatekoaren arabera & $\% 21$ & $\% 13$ & $\% 18$ & $\% 15$ & $\% 18$ & $\% 23$ \\
\hline Ez & $\% 57$ & $\% 76$ & $\% 75$ & $\% 74$ & $\% 66$ & $\% 71$ \\
\hline Ez dakite & $\% 9$ & $\% 2$ & $\% 3$ & $\% 2$ & $\% 3$ & $\% 2$ \\
\hline
\end{tabular}




\subsection{Azkartasunaren eta sakontasunaren arteko bateragarritasunak}

Profesionalei zuzenduriko galdera irekien artean, 21 ak honakoa zioen hitzez hitz: "Iruditzen zaizu, esperientzia zabaleko profesional gisa, kalitatea, azkartasuna eta egiazkotasuna bateragarriak direla egun?". Baiezko bezainbeste ezezko jaso dira, baina guztiek ere ñabardura asko eman dituzte. Gorka Zabaleta Baleike tokiko aldizkariko zuzendariak adibidez, honela dio: "Ezinbestekoa da komunikazioaren merkatuan lehiakorra izateko. Azkartasuna egiazkotasunaren aurretik jarriz gero, ordea, akabo sinesgarritasuna, akabo kazetaritza. Kalitatean patxadak laguntzen du baina ez da erabakigarria. Kazetariaren prestakuntza eta gaitasuna dira erabakigarriak". Edo Juan Carlos Martinezek, Correo egunkariaren zuzendariak, honela erantzuten du: "Azkartasuna ezinbestekoa da, baina, aldi berean, kalitateaegiazkotasuna binomioaren arerio nagusi". Deigarria da, berriro ere, irakurleekiko aldea: kasu horretan \% 90k jotzen du bateragarri azkartasuna, kalitatea eta egiazkotasuna hirukoa.

Europan, profesionalei egindako inkestan, \% 57k erantzun du bateragarriak direla ezaugarri hauek guztiak eta \% 43k ezetz, batekoek eta bestekoek ñabardura ugari jarri badituzte ere. Joan Barrilek, esaterako, El Periódico de Catalu$\tilde{n} a$ ko zutabegile ezagunak, honakoa zioen: "badaude urte asko horretara emanak igaro ondoren kalitatea, azkartasuna eta egiazkotasuna uztartzeko gaitasuna garatzen duten kazetariak". Vilaweben zuzendari Vicent Partalek "bai posible da, zalantzarik gabe" erantzun du labur. Luois Oliverrek (TF1) ñabardurekin ematen du baiezkoa: "Bai posible da, baina horretarako kazetariek joko arau berriak onartu beharko lituzkete: ordu gehiago sartu beharra, soldatak banatu beharra...". .Il Fatto Quotidiano-ko Peter Gomezek osatzen du erantzuna: "editoreak talde lanean aritzeko antolatu beharko lirateke, istorio berean esku gehiago jarri lanean". Il Messaggero-rentzat freelance gisa lan egiten duen Paolo Gobbi, aldiz, ezezkoan dago: "kalitatea normalean denborari lotzen zaio, azkartasuna eta kalitatea nekez ezkontzen dira".

Irakurleak, beste behin ere, baikorrago agertzen dira: \% 55ak baiezkoa erantzuten du; \% 36ak uztartu daitezkeela azkartasuna, kalitatea eta egiazkotasuna, baina zaila suertatu daitekeela, eta \% 3k bakarrik jo du ezinezkotzat.

\subsection{Adierazpen askatasuna, informatzeko eskubidea}

Adierazpen askatasunari inguruan topa daitezke kazetarien eta irakurleen arteko kointzidentzia batzuk. Gehiago dira digitalean askatasun handiagoa dagoela irizten diotenak, alderantzizko iritzia dutenak baino; hala ere, bai irakurleen eta bai kazetarien kasuan, gehiengo zabal batek sarean nahiz hedabide tradizionaletan antzera ikusten dute kontua. Dena dela, seinalatu daiteke diferentzia txiki bat: hedabide tradizionalen aldeko hautua egiten dutenen artean irakurleak dira gehiengoa. Europako inkestetan, digitalaren hautua are nabarmenagoa da, profesionalen $\% 52$ eta irakurleen $\% 40$. 
11. grafikoa. Nork bermatzen du hobeto adierazpen askatasuna?

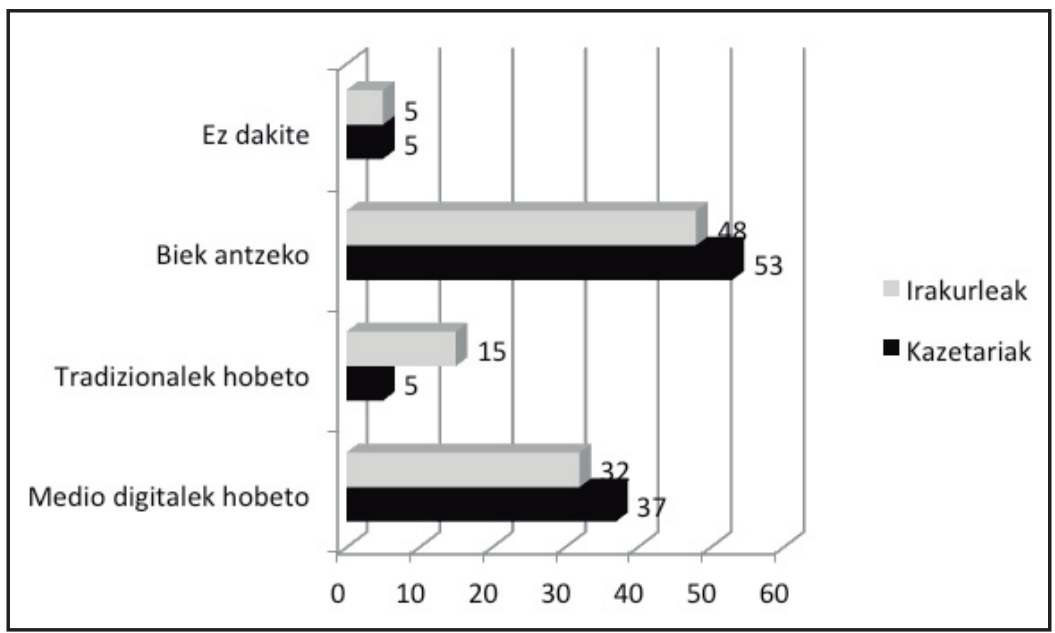

Iturria: UPV/EHUko HGH Ikerketa Taldeak diseinaturiko inkestetan oinarriturik HGH taldeak berak eta CIESek buruturiko galdeketak.

12. grafikoa. Adierazpen askatasunaren mehatxuak.

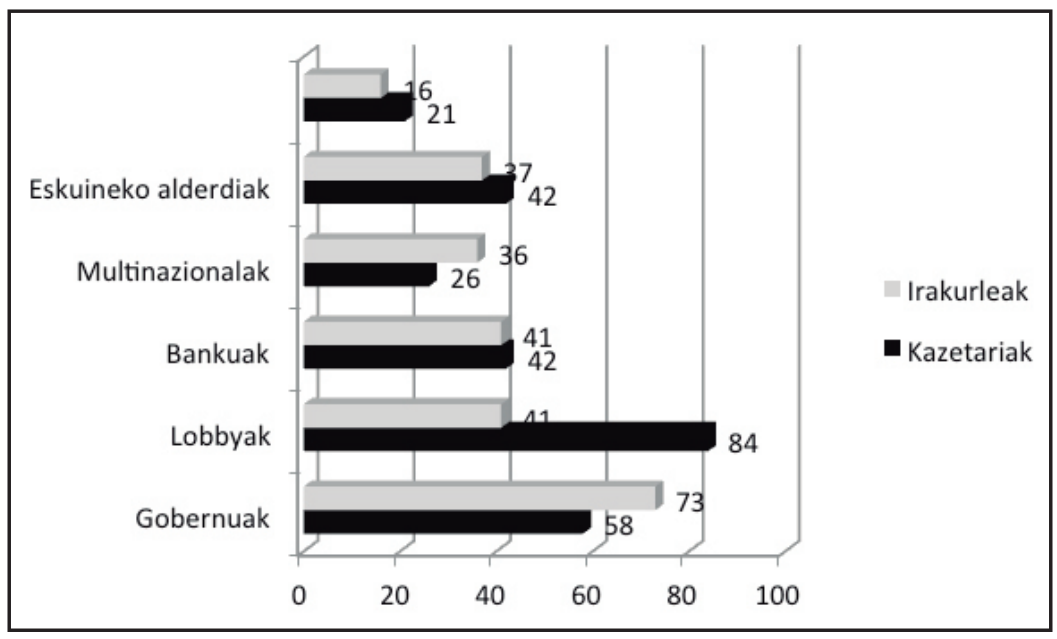

Iturria: UPVIEHUko HGH Ikerketa Taldeak diseinaturiko inkestetan oinarriturik HGHtaldeak berak eta CIESek buruturiko galdeketak.

Galdetegiak adierazpen askatasuna eta egiazko informazioa jasotzeko eskubideak bereizten ditu. Lehenengoari dagokionez, irakurleek eta kazetariek sarekoa tradizionala baino hobeto ikusten dute, baina, bigarrenari buruz, iritzi desberdinak dituzte: irakurleen ustez, medio digitalek hobeto betetzen dute funtzio hori (\% 36) tradizionalek baino (\% 11); kazetarien iritziz, tradizionalak txukunago aritzen dira (\% 58) digitalak baino (\% 5).

Europan ere modu berean jasotzen dira tendentzia horiek guztiak. Adierazpen askatasuna egikaritzeko egokiago ikusten dute medio digitala bai irakurleek (\% 40 
digitalak eta \% 12 tradizionalak) eta baita kazetariek ere (\% 52 digitalek eta \% 9 tradizionalek). Egiazko informazioa jasotzeko eskubidea bermatzeko egokitasunaren inguruan, ordea, ez dago sintoniarik: irakurleek digitalen alde egiten dute (\% 26 vs. $\%$ 16) eta profesionalek tradizionalen alde (\% 52 vs. \% 9).

Adierazpen askatasuna mehatxatzen duten eragileen inguruan bat datoz Euskal Herriko erabiltzaileak eta kazetariak. Profesionalek lobby politiko, sozial eta ekonomikoei emaniko garrantzia salbu.

Gobernuak (\% 60), lobbyak (\% 48), multinazionalak (\% 38) eta eskuineko alderdi politikoak (\% 30) aipatzen dituzte Europako erabiltzaileek, hurrenez hurren, lau mehatxu garrantzitsuenen artean. Europako kazetariek lobbyak (\% 67), gobernuak (\% 50), multinazionalak (\% 46) eta bankuak (\% 30).

\subsection{Medio digitalek hobetu beharrekoak}

Sarean hobetu beharrekoez ere galdetu zaie batzuei eta besteei. 13. grafikoan ikus daitekeen bezala, nabarmena da kazetariek baino askoz garrantzi handiagoa ematen diotela irakurleek interaktibotasunari. Aitzitik, kazetariek garrantzia handiagoa ematen diote sarean kontatzeko modu propioak garatzeari. Europan ere interaktibotasunari buruzko datuak errepikatu egiten dira: \% 2k bakarrik aipatu ditu kazetarien artean eta \% 18k irakurleen artean. Kazetarien artean aitatuena, aldiz, sakontasuna da, \% 56, irakurleen kasuan \% 29ak seinalatzen duelarik.

13. grafikoa. Medio digitalek hobetu beharrekoak.

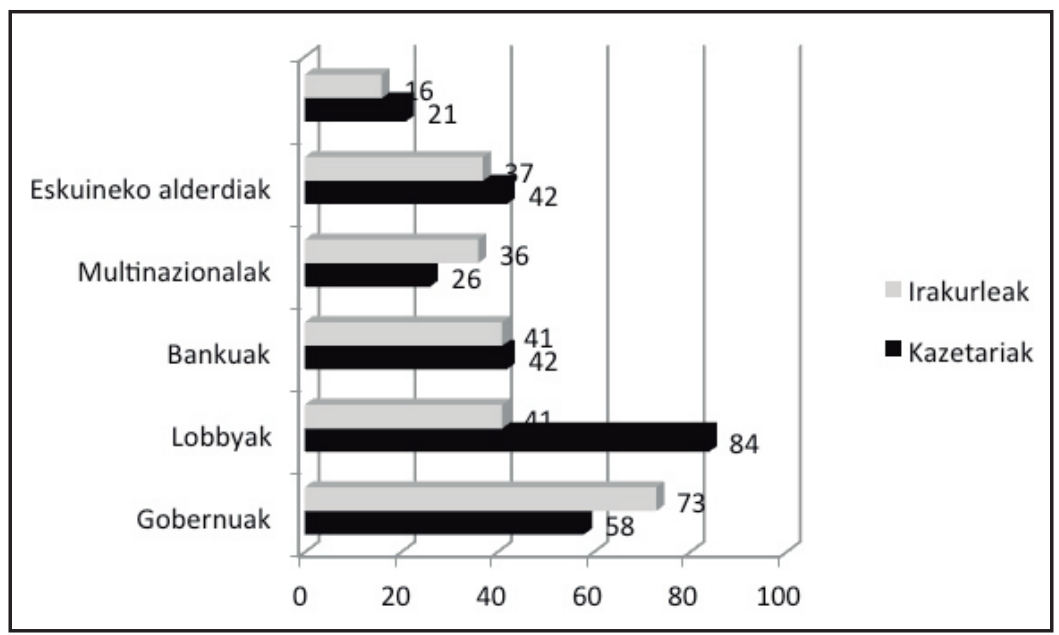

Iturria: UPV/EHUko HGH Ikerketa Taldeak diseinaturiko inkestetan oinarriturik HGH taldea berak eta CIESek buruturiko galdeketak.

Paradoxikoki, irakurleek abstraktuan eskatzen duten interaktibotasuna, gero ez dute eskatzen link eta ikus-entzunezko bitartekoen kopuruaz galdetzen zaienean. Euskal Herrian irakurleen \% 10ek ez du beharrezko ikusten linken erabilera 1.500/2.000 karakteretako testu batean, \% 13ak nahikoa du bakarrarekin eta \% 10ak birekin. Kazetariak zorrotzagoak dira alor honetan: ez dago linkin gabeko edo link bakarreko 
testurik ontzat ematen duen inor, \% 16ak jarriko lituzke bi link, eta \% 21 bost baino gehiago jartzearen aldeko azaltzen da (irakurleen kasuan \% 7 bakarrik dago aukera horren alde).

Europan ere antzeko fenomenoa ematen da. Link kopuru txikienak hobesten dituzten portzentajeak altuagoak dira irakurleen artean, eta link kopuru altuenak hobesten dituztenak altuagoak kazetarien artean. Hala ere ezberdintasunak leunagoak dira, eta bai irakurleen gehiengoak (\% 56) eta bai kazetarienak (\% 55) bi edo hiru link arteko aukeren alde egiten dute.

Halaber, multimedia elementuen erabilerari gagozkiolarik, are nabarmenagoak dira irakurleen eta kazetarien arteko ezberdintasunak. Euskal Herrian, kazetarien gehiengoak (\% 53) ikus-entzunezko bi elementu txertatuko lituzkete 1.500/2.000 karaktereko testu batean. Irakurleen artean \% 9koa da hautu hori egiten dutenen portzentajea. Gehiago dira ikus-entzunezko elementurik sartuko ez luketenak (\% 13) eta bakarra sartuko luketenak (\% 14).

Europan, berriro ere, fenomeno bera ematen da baina modu leunagoan. Kazetarien gehiengoak bi (\% 39) edo hiru (\% 28) ikus-entzunezko elementu txertatuko lituzke. Irakurleen gehiengoak, aldiz, bat (\% 26) edo bi (\% 30).

Agerikoa da, bada, kazetariak ohituagoak daudela irakurketa modu berrietara eta sareko kazetaritzak dauzkan potentzial berrietara, eta Europako irakurlea Euskal Herrikoa baina zerbait errazago moldatzen dela berrikuntzetara.

\subsection{Jomuga 2020an}

Azkenik, bai kazetariei, bai irakurleei 2020an paperekoak izan zezakeen errealitatea irudikatzeko eskatzen zitzaien, izan ere, prestigioko zenbait akademikok (Martínez Albertos, 1998: 35) hor jarri zuten prentsa idatziaren iraungitze data. Hauxe da kazetari eta irakurleek irudikatzen dutena.

14. grafikoa. Papereko informazioa 2020an.

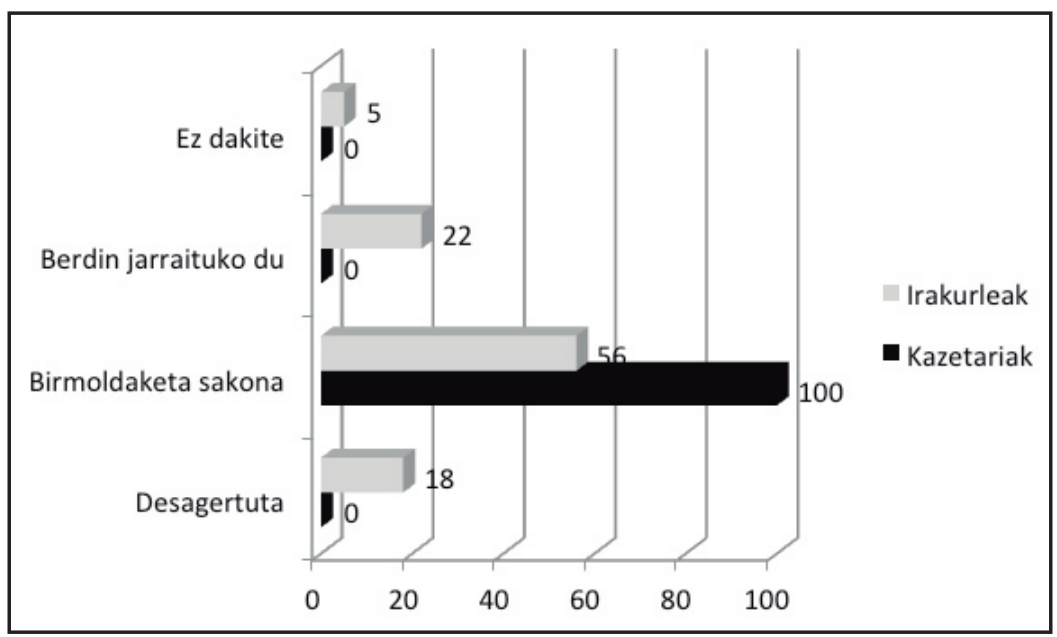

Iturria: UPV/EHUko HGH Ikerketa Taldeak diseinaturiko inkestetan oinarriturik HGH taldea berak eta CIESek buruturiko galdeketa. 
Beste behin, ez datoz bat batzuk eta besteak. Irakurleen gehiengoak birmoldaketaz dihardu, baina badago desagertu egingo dela edota denak berdin jarraituko duela pentsatzen duenik ere. Kazetariek, ordea, irizten diote egungo joeretan sakonduz paperekoak teknologia eta euskarri berrietara egokituz birmoldaketa sakon bat beharko dutela. Gorka Zabaleta, Baleikeren zuzendariaren irudikapena honakoa da: "Informazio jario handiena gailu mugikorretatik bideratuko da. Kazetaritza profesionalak aurrera egingo du baliodun edukiak eskaintzen dituen neurrian. Eta euskarazko hedabideei dagokienez, sarean antolatuta irudikatu nahiko nituzke, tokikoak eta nazionalak, baliabideak modu eraginkorrean erabiltzen, komunitateari begira lanean...". Eta Juan Mari Gastacak, El País egunkariaren Euskadiko edizioaren zuzendariak, honakoa gaineratzen du: "Ordainpeko egunkariak sarean egongo dira eta espezializatuak paperean".

Europako inkestek ere antzeko emaitzak eskaintzen dituzte: profesional gehienek birmoldaketa ikusten dute, \% 83; irakurleen \% 58ren aurrean. Irakurle gehienek ere hautu hori egiten dute, baina profesionalen artean baino gehiago dira desagertuko dela aurreikusten dutenak (\% 4 profesionalak eta \% 16 irakurleak).

15. grafikoa. Sareko informazioa 2020an.

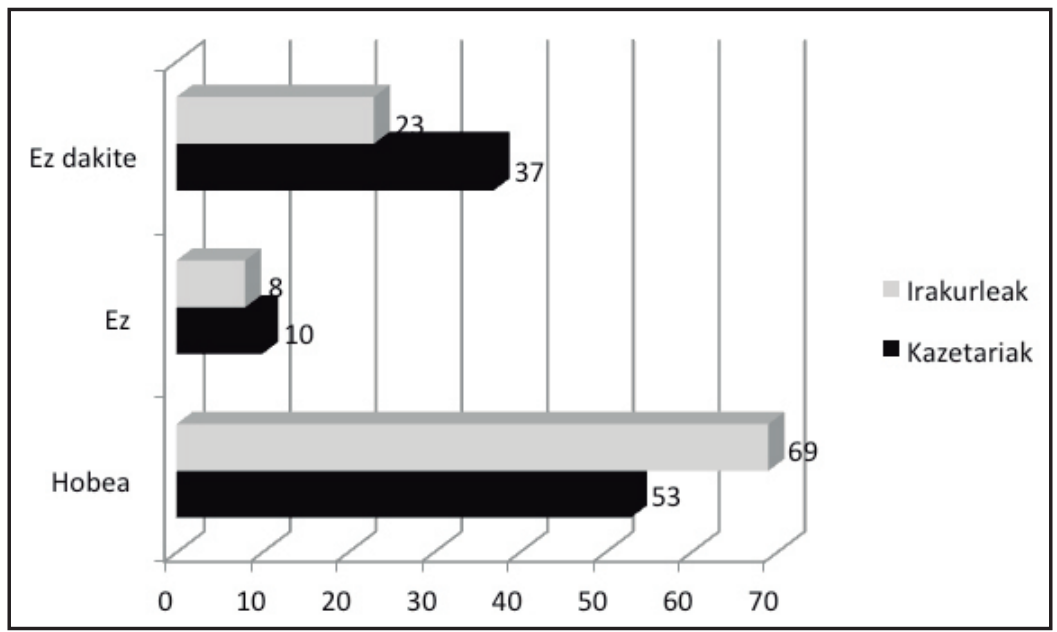

Iturria: UPV/EHUko HGH Ikerketa Taldeak diseinaturiko inkestetan oinarriturik HGH taldea berak eta CIESek buruturiko galdeketak.

Sareko hedabideen etorkizunaren inguruan ere galdetu zaie eta badirudi irakurleak zerbait baikorragoak direla. Europako inkestetan kazetariak dira baikorragoak (\% 76 kazetariak vs \% 71 irakurleak).

Azkenik, sareko informazioak 2020an nolako ezaugarriak izan ditzakeen galdetu zaie bateko nahiz besteko irakurle eta kazetariei. Eta Euskal Herriko erantzunetan, bai irakurleek (\% 74) eta bai kazetariek (\% 84) eduki interaktiboagoak izango direla aipatzen dute lehenik eta behin. Sakonagoa izango dela uste du irakurleen \% 42ak eta kazetarien \% 53ak, testu laburragoak izango direla irakurleen \% 25ak eta 
kazetarien \% 32ak, eta hedabide digitaletako informazioa azalekoagoa izango dela iragartzen dute, aldiz, irakurleen \% 25ak eta kazetarien \% 32ak.

Europako datuetan, interaktibotasuna areagotuko dela uste dutenen portzentajeak altuagoak dira (irakurleen \% 83 eta kazetarien \% 83) eta beste hainbeste gertatzen da edukiak sakontasun handiagoarekin landuko direla uste dutenekin (irakurleen \% 49 eta kazetarien \% 48).

Argi dago bada, gehiengoa bat datorrela 2020ko sareko informazioa hobea, interaktiboagoa eta sakonagoa izango dela irudikatzerakoan, Europan baikortasun hori Euskal Herrian baina zerbait nabarmenagoa den arren.

\section{Ondorioak}

1. Hedabide digitaletako kazetarien eta irakurleen iritziek ez dute bat egiten inkesta bidez planteatu zaizkien hainbat kontu garrantzitsutan. Kazetarien iritziak, agerikoa denez, landuagoak, zorrotzagoak eta ñabardura gehiagokoak dira, barrutik ezagutzen baitute profesioa. Irakurleen iritziak, ordea, oso kontuan hartu beharrekoak dira, euren erabakiz mugitzen baita merkatua, batera edo bestera. Horrela, adibidez, irakurleei kazetariei baino arrotzagoa egiten zaie ordainpeko formula, gutxiago kontsumitzen dute, eta kazetariak orokorrean kritikoagoak dira dagoen eskaintzarekin. Doakoaren kasuan, ezberdintasun hori askoz nabarmenagoa da: irakurleak askoz ere konformeago agertzen dira kazetariak baino. Ordainpekoaren ahulguneak aipatzerakoan, aitzitik, irakurleek kalitatearen eta prezioaren arteko harreman eskasa nabarmentzen dute bereziki, eta kazetariek bestelako alderdiak azpimarratzen dituzte.

2. Sareko edukiak ordainpean jartzeko joera hedatu nahi den honetan, Euskal Herriko irakurleen gehiengoa aurka azaltzen da: \% 64, hain zuzen; aldiz, kazetarien \% 58k irakurleak ordaintzeko prest ikusten ditu. Irakurleen $\% 77$ gustura daude doakoak eskaintzen dienarekin. Informazio enpresek kontuan hartu beharko dituzte joera horiek, beraien irudimena zorroztu, eta gainbalio garbia duten ordainpeko edukiak eskaini. Halaber, ezinbestekoa dirudi irakurleen artean pedagogia egiteak: doakotasunaren kulturak lausotu egin du ongi landuriko informazio ororen atzetik informazioa jaso, hautatu, egiaztatu, hierarkizatu eta analizatzen duten kazetarien lana. Lan horrek guztiak kostu bat du, ordea. Gainera, ongi landuriko informazioa ezinbestekoa da herritarren izpiritu kritikoa eta gizarte baten izaera demokratikoa bermatzeko.

3. Euskal Herriko eta Europako inkesten artean ere badaude alde esanguratsuak. Euskal Herrian jasotako erantzunetan Europakoetan baino arrotzagoa da ordainpeko formula. Hala ere, eta hau ere beste ezberdintasun garrantzitsu bat da, ordaintzeko prestasun handiagoa erakusten dute euskal irakurleek. Orobat sarean bertan egunkari digitalek pisu handiagoa dute gainerako medioekiko euskal inkesten kasuan, egunkari gogokoenarekiko fideltasuna esanguratsuagoa da Europakoen kasuan 
baino, eta konektatzeko erabiltzen diren gailuak tradizionalagoak dira. Hala ere, joera globalak dira nagusi, hau da, batzuen eta besteen arteko antzekotasunak. Honela, aurreko bi puntuetan euskal irakurleei buruz esaniko guztiak europarrengana ere estrapola daitezke, antzeko proportzioetan gainera.

4. Azkartasuna, kalitatea eta egiazkotasuna bateratzeko aukerak bitan banatzen ditu euskal kazetariak, Europakoen artean gertatzen den bezalaxe. Aipatzen diren ñabardurek erakusten dute teknologia berriek inposatu duten azkartasunak asko zailtzen duela aldi berean kalitatea eta egiazkotasuna lortzea. Irakurleek, aldiz, batean nahiz bestean baikorrago azaltzen dira ezaugarri horiek uztargarri egiteko orduan.

5. Kazetari nahiz irakurleak bat datoz adierazpen askatasuna mehatxatzen duten agenteak seinalatzerakoan: lobby politiko, sozial eta ekonomikoak, gobernuak, multinazionalak, bankuak eta alderdi politikoak. Eta bat egiten dute baita medio tradizionaletan nahiz sarean adierazpen askatasuna antzera bermatzen dela baieztatzerakoan, digitalen aldeko hautua egiten dutenak gehiago diren arren. Informazio eskubideari dagokionez, aldiz, dibergentzia dago: Kazetariek, bai Euskal Herrian eta bai Europan, medio tradizionalek funtzio hori hobeto betetzen dutela ikusten dute; irakurleek, aitzitik, bai Euskal Herrian eta bai Europan, digitalek hobeto egiten dutela irizten diote.

6. Kazetariek eta irakurleek modu kritikoan begiratzen diote etorkizunari. Euskal profesional guztiek argi dute paperekoak eutsi egingo diola 2020an baina birmoldaketa garrantzitsua beharko duela, eta irakurleen gehiengoa bat dator horrekin, desagertu egingo dela uste duenik ere badagoen arren. Sarekoak interaktibotasun eta sakontasun gehiago izango dituela eta hobea izango dela uste dute batzuek nahiz besteek, irakurleak baikorrago azaltzen diren arren. Europan berretsi egiten dira joera horiek guztiak.

7. Hainbat euskal hedabide community media bezala definitzen den eredu horretatik oso gertu daude. Hizkuntza gutxiagotuan argitaratuta eta Estaturik ez duen komunitate batean txertatuta, komunikabide horien egitekoa ezinbestekoa da euren komunitatearentzat. Euskal Inkesta eta Europakoa alderatuta, lotura hori agerian gelditzen da hainbat detailetan. Esaterako, euskal irakurleak fidelagoak dira euren egunkariekiko eta ordaintzeko prestasun handiagoa erakusten dute. Lotura hori funtsezkoa izango da euskal hedabideen etorkizunean ere. 


\section{Erreferentzia bibliografikoak}

APM, Asociación de la Prensa de Madrid (2013). Informe de la Profesión Periodística. [http://www.apmadrid.es/noticias/generales/informe-de-la-profesionperiodistica-2013-11151-empleos-perdidos-y-284-medios-cerrados-desde2008? Itemid=209] 2014-06-09.

AIESTARAN, Alazne (2007). Deba Barreneko euskarazko komunikazio sistema: tokian tokiko aldizkarien kazetaritza-genero eta gaien analisia 2000-2004 bitartean (eta Kitto, Pil-pilean, Barren, Berriketan, Kalaputxi eta Drogetenitturri). Bilbao: EHU/UPV, Argitalpen Zerbitzua.

AIESTARAN, Alazne (2010). Euskarazko herri-prentsaren irakurleen profila aztergai. In Uztaro, 74, 59-72.

AIESTARAN, Alazne et al. (2014). Kalitate-indizeak euskarazko kazetaritzan. En: Uztaro, $\mathrm{n}^{\circ}$ 91, pp. 41-64.

ARANA et al. (2010). Euskarazko hedabideak. Bilbao: UPV/EHU.

BALLESTEROS, Cecilia (2012). Los ojos de la historia (reciente). En: AYESTARAN, Mikel. et al. (2012). Queremos saber. Cómo y por qué la crisis del periodismo nos afecta a todos. Barcelona: Debate.

BOGART, Leo (2004).Reflections on Content Quality in Newspapers. En: Newspapers Research Journal, $\mathrm{n}^{\circ}$ 25(1), pp. 40-65.

CAMACHO, Idoia (2002). Herri aldizkarien funtzioa euskara normaltzeko prozesuan (1989-1999). Bilbao: EHU Argitalpen Zerbitzua.

DÍAZ NOCI, Javier (2012). Historia del periodismo vasco (1600-2010). In Mediateka 13, 1-261. Donostia: Revista de Estudios Vascos.

JARVIS, Jeff (2007). Newspapers in 2020. New architecture, news innovation, newspapers. [http.//buzzmachine.com/newspapers-in-2020/] 2014-10-20.

LEIVA, Ricardo; VARA-MIGUEL, Alfonso (2010): La estrategia 'freemium': Una alternativa para crear valor y cobrar por loscontenidos periodísticos especializados en Internet. En: QUESADA PEREZ, Montse. (ed) Internet como fuente generadora de contenidos especializados. Barcelona: Univ. Pompeu Fabra, pp. 338-355.

MARTINEZ ALBERTOS, José Luis (1998). El ocaso del periodismo (en papel). Madrid: CIMS.

MEYER, Philip (2004). The Vanishing Newspaper: Saving Journalism in the Information Age. Columbia: University of Missouri Press.

MORALES, Lymari (2013). U.S. Distrustin Media Hits New High Fewer Americans closely following political news now than inpreviou selection years. [http://www. gallup.com/poll/157589/distrust-media-hits-new-high.aspx] 2014-10-28.

NOBRE, José Manuel (2010). La Europa de los medios frente a la crisis. En: Infoamérica , 2, pp. 89-104. [http://www.infoamerica.org/icr/n02/nobre\% 20_correia. pdf] 2014-10-22.

PABLOS DE, José Manuel; MATEOS, C. (2004). Estrategias informativas para acceder a un periodismo de calidad, enprensa y TV. Patologías y tabla de 'medicación' para recuperar la calidad en la prensa. En: Ámbitos, $n^{\circ}$ 11-12. pp. 341-365.

PÉREZ-LATRE, Francisco Javier; SÁNCHEZ-TABERNERO, Alfonso (2012). Innovación en los medios. La ruta del cambio. Pamplona: Eunsa. 
PÉREZ-TORNERO, José Manuel (2008). Crisis y pérdida de confianza en los medios. [http://jmtornero.wordpress.com/2008/10/11/crisis-y-perdida-de-confianza-en-los-medios-i/] 2014-05-22.

PEW RESEARCH CENTER (2014). The revenue picture for American journalism, and how it is changing. Whasington. PewResearch Center.

PICARD, Robert (2004). Commercialism and newspaperquality. En: Newspaper Research Journal, $\mathrm{n}^{\mathrm{O}}$ 25(1), pp. 54-65.

RAMIREZ DE LA PISCINA, Txema et al. (2014a). Periodismo de calidad en tiempos de crisis: Un análisis de la evolución de la prensa europea de referencia (2001-2012). En: Revista Latina de Comunicación social, nº 69, pp. 248-274.

RAMIREZ DE LA PISCINA, Txema et al. (2014b). Differences between the quality of the printed version and online edition of the European reference press. Journalism, july 2014, pp. 1-24.

RAMIREZ DE LA PISCINA, Txema et al. (2015a). The future of Journalism: Who to believe?. En: Journalism Practice, february 2015, pp. 1-23.

RAMIREZ DE LA PISCINA, Txema et al. (2015b). Kazetaritzaren garabideak: Kalitatea, berrikuntza eta prestakuntza. En: Uztaro, no 93 , pp. 19-42.

RAMONET, Ignacio (2011). La explosión del periodismo. De los medios de masas a la masa de medios. Madrid: Clave intelectual.

REQUENA, Pilar (2012). El tiempo robado. En: AYESTARAN, Mikel et al. Queremos saber. Cómo y por qué la crisis del periodismo nos afecta a todos. Barcelona: Debate.

RODRIGUEZ COTO, Sandra (2012). Predicciones 2012: tendenciasenelperiodismo y losmedios[http://www.80grados.net/predicciones-2012-10-tendencias-en-elperiodismo-y-los-medios/] 2014-10-20.

SALAVERRÍA, Ramón (2012). Medios y periodistas, ¿un futuro compartido? En: Cuadernos de comunicacion Evoca, (El futuro del Periodismo), 7, pp. 11-15.

SMITH, Anthony (2010). El periódico que viene. Reconstrucción del escenario mediático. En: La crisis de la prensa. Infoamérica, Iberoamerican Communication Review, vol. 2, pp. 7-19.

STANDARD EUROBAROMETER 76 (2012). Media Use in the European Union. [http://ec.europa.eu/public_opinion/archives/eb/eb76/eb76_media_en.pdf] 2014-10-23.

STARR, Paul (2010). Menos prensa, máscorrupción. En:Iberoamerican Communication Review. La crisis de la prensa. Infoamérica, vol. 2. pp. 69-87.

WAN-IFRA World Association of Newspapers and News Publishers (2012): World Press Trends Report 2012.[http://www.wan-ifra.org/es/press-releases/2012/08/30/world-press-trends] 2014-11-23.

WIMMER, Roger; DOMINICK, Joseph (1996). La research científica de los medios de comunicación. Una introducción a sus métodos. Barcelona: Bosch.

ZABALETA, Iñaki (1997). Komunikazioaren eta ikerkuntzako metodologia. Bilbao: Udako Euskal Unibersitatea. 
ZABALONDO, Beatriz (2011). El euskera en los medios-Los medios del euskera. In HABOUD, Marleen; OSTLER, Nicholas (ed.) Endangered Languages: Voices and Images / Voces e Imágenes de las Lenguas en Peligro. Bath: Foundation of Endangered Languages.

ZUBEROGOITIA, Aitor (2003): Euskararen presentzia gaur egungo prentsa elebidun abertzalean. Bilbao, UPV/EHU Argitalpen Zerbitzua. 